Sains Malaysiana 49(9)(2020): 2323-2333

http://dx.doi.org/10.17576/jsm-2020-4909-29

\title{
Empty Fruit Bunch Cellulose based Sorbent for Oil Sorption in Palm Oil Mill Effluent
}

(Penjerapan Selulosa Tandan Kosong Kelapa Sawit untuk Penjerapan Minyak daripada Efluen Kilang Minyak Kelapa Sawit)

\author{
NORAisAH JAHI, RizafizaH Othaman, AZWAN MAT LAZIM \& SURIA RAMLI*
}

\begin{abstract}
The aim of this study was to develope hydrophobic biodegradable cellulosic sorbent materials from empty fruit bunch (EFB) for oil sorption in palm oil mill effluent (POME). EFB cellulose was modified using acetic anhydride (AA) and the effect of ratio of EFB cellulose mass to $A A$ volume $(1: 20,1: 30,1: 40,1: 50 \mathrm{~g} / \mathrm{mL})$ at $3 \mathrm{~h}$ reaction time with $5 \%$ $(w / v)$ pyridine catalyst. The acetylation process was quantitatively determined using the weight percent gain (WPG) and modified EFB cellulose (1:40) showed the highest WPG (13.0\%) compared to the other ratios. Fourier Transform Infrared (FTIR) spectrum shows that after the modification, the intensity of $-O H$ peak at $3329 \mathrm{~cm}^{-1}$ decreased and the new peak at $1728 \mathrm{~cm}^{-1}$ of $C=O$ ester emerged. This implied that acetylation process was successful when AA volume increased except for 1:50 ratio. Sample 1:40 also showed good hydrophobicity characteristic with the degree of hydrophobicity (DH) of 87.7\%. X-ray diffraction (XRD) analysis shows that crystallinity index for 1:40 is the lowest which indicated that the sample become amorphous due to acetylation. The result is in agreement with scanning electron microscope (SEM) micrograph that shows the surface morphogy of EFB cellulose after the modification became rougher. Moreover, the modified EFB cellulose 1:40 was able to absorb oil from POME up to 98.5\%. Thus, it is proven that cellulose from EFB can be modified to a certain ratio to make it an extremely promising natural source oil sorbent in treating POME.
\end{abstract}

Keywords: Cellulose; chemical modification; oil adsorbent; palm oil mill effluent

\section{ABSTRAK}

Kajian ini bertujuan untuk membangunkan selulosa hidrofobik biodegradasi bahan penyerap daripada sisa tandan kosong kelapa sawit (TKKS) bagi penyerapan minyak efluen kilang kelapa sawit (POME). Selulosa EFB telah diubah suai menggunakan asetik anhidrida dan kesan nisbah berat selulosa daripada TKKS kepada isi padu asetik anhidrida (AA) $(1: 20,1: 30,1: 40,1: 50 \mathrm{~g} / \mathrm{mL})$ dalam masa tindak balas 3 jam dengan 5\% (w/v) pemangkin piridina. Proses pengasetilan ditentukan secara kuantitatif menggunakan peratus pertambahan berat (WPG), dan selulosa TKKS terubah suai (1:40) menunjukkan WPG tertinggi (13.0\%) berbanding nisbah yang lain. Spektrum teknik inframerah transformasi Fourier (FTIR) menunjukkan selepas pengubahsuaian, keamatan puncak-OH pada $3329 \mathrm{~cm}^{-1}$ berkurang dan puncak baru pada $1728 \mathrm{~cm}^{-1}$ daripada $C=O$ ester telah muncul. Ini menunjukkan bahawa proses pengasetilan telah berjaya apabila isi padu AA meningkat kecuali pada nisbah 1:50. Sampel 1:40 juga telah menunjukkan ciri hidrofobik yang baik dengan darjah kehidrofobikan (DH) pada 87.7\%. Analisis pembelauan sinar-x (XRD) menunjukkan peratus indeks kehabluran untuk 1:40 adalah terendah yang menunjukkan sampel berkenaan menjadi amorfus disebabkan oleh asetilasi. Hasil keputusan adalah seiring dengan mikrograf analisis morfologi dan keratin rentas (SEM) yang menunjukkan morfologi permukaan selulosa EFB selepas pengubahsuaian menjadi lebih kasar. Tambahan lagi, selulosa EFB termodifikasi 1:40 berupaya untuk menyerap minyak daripda POME sehingga 98.5\%. Oleh itu, ini membuktikan bahawa selulosa daripada EFB boleh diubah suai kepada nisbah tertentu untuk menjadikannya sumber penyerap minyak semula jadi dalam merawat POME.

Kata kunci: Efluen kilang minyak kelapa sawit; pengubahsuaian kimia; penjerapan minyak; selulosa

\section{INTRODUCTION}

Malaysia is well known as one of the biggest producers and exporters of palm oil and palm oil products (Hazman et al. 2018; MPOB 2015). Malaysia Palm Oil Board (MPOB) has reported that in 2015, palm oil mills processed about 98.34 million tonnes of fresh fruit bunch (FFB) in Malaysia (MPOB 2015). Along with the extraction process 
of crude palm oil and palm kernel from FFB, considerable amounts of by-products such as fiber, shell, empty fruit bunch (EFB) and palm oil mill effluent (POME) are also generated (Hassan et al. 2019).

POME is a non-toxic thick brownish liquid waste which has unpleasant odour (Takriff et al. 2014) and is considered the most harmful waste for the environment if discharged to waterway untreated (Hamzah et al. 2019). POME has typical properties like biochemical oxygen demand (BOD) of $25000 \mathrm{mgL}^{-1}$, chemical oxygen demand (COD) of $50000 \mathrm{mgL}^{-1}$, suspended solids of $20000 \mathrm{mgL}^{-1}$, total solid of $40000 \mathrm{mgL}^{-1}$ and oil and grease of $8000 \mathrm{mgL}^{-1}$ (Ibrahim et al. 2010). The residual oil has to be removed from the wastewater to avoid problems in subsequent water treatment units and biological treatment stages. The application of oil sorbents based on natural fibre may offer an opportunity to alleviate the current environmental crisis, especially water contamination from oil spills and industrials waste (Hamdan et al. 2018; Hassan \& Puteh 2007; Jasni et al. 2020). The sorbent material to adsorb oil waste must be hydrophobic in character. Natural sorbent materials for oil sorption that are commonly used are cotton, bagasse, rice husk, barley straw, kapok, and wood waste (Jahi et al. 2015).

Oil palm biomass residues are generated throughout the year include empty fruit bunches (EFB), palm press fiber (PPF), palm kernel cake (PKC), palm kernel shell (PKS), decanter cake (DC) in palm oil mills and liquid waste as palm oil mill effluent (POME) (Anuar et al. 2018; Yamada et al. 2010). EFB is the most abundant solid waste in the palm oil processing industry and almost 1.07 tonnes of EFB have been generated for each tonne of palm oil processed (Kassim et al. 2017). In order to protect our ecosystem and sustaining the palm oil industry, some efforts have been made recently to recyle these EFB wastes in many applications. Among others; EFB was utilized for value added products such as biosorbent (Collin 2015), bio-adsorbent, bio-oil, pulp, and activated carbon (Roslan 2014). Lignocellulose is one of the main component of EFB fibers that composed of cellulose (43.0\%), hemicelluloses (35.8\%), and lignin (16.4\%) (Hamzah et al. 2011).

The research in lignocellulose material such as cellulose from EFB has been gaining lots of attention in recent years and increasing due to the fact that $\mathrm{EFB}$ have a continuous source that is readily available, easy to handle, renewable and cheap (Mahadeva et al. 2011; Zakaria et al. 2014). Cellulose was widely used as composite materials, component in drug delivery, adsorbent (Abdullah et al. 2010), furniture, pulp and paper, and high potential bio-fuel (Pirani \& Hasaikeh 2013). Despite being effective sorbent for oil sorption, the hydroxyl groups located on cellulose fiber have hydrophilic properties that may affect its efficiency and oil uptake capacity in aqueous system (Deschamps et al. 2003). This problem can be overcome by replacing hydroxyl groups by hydrophobic acetyl groups through acetylation (Chen et al. 2016).

Studies have been reported on the preparation of a oil-spill adsorbent using acetylation of natural fibres; Delonix regia pods (Onwuka 2016), wheat straw fiber (Lv et al. 2017) and EFB cellulose fiber (Asadpour 2016; Onwuka 2018; Sajab et al. 2018) for crude oil treatment. In spite of that, POME treatment by EFB biomass as oil absorbent is still new and not yet been fully explored. In previous study, oil palm leaves (OPL) and oil palm frond (OPF) were modified as oil adsorbent for POME (Jahi et al. 2015). In the present work, instead of OPL and OPF, cellulose from EFB was modified by acetylation with AA in varied ratios using pyridine as catalyst. The capability of the modified EFB cellulose to absorb oil waste in POME was studied and compared with the unmodifed EFB cellulose. The significant of this research is to reduce solid wastes of EFB and at the same time recover the oil from POME for the sustainability of palm oil industry.

\section{MATERIALS AND METHODS}

\section{MATERIALS}

Chemicals used in this research were sodium hydroxide pellet ( $\sim 99 \%$ purity) glacial acetic acid (99.8 wt. \%), acetone, sodium chloride powder, acetic anhydride $(>98 \%$ purity), and pyridine (99.8\%). They were supplied by Science Fischer (M) Sdn. Bhd. company. The raw EFB fiber was obtained from Szetech Engineering Sdn. Bhd. The EFB fibres were rinsed with distilled water several times until all the fine dust present were removed and then were dried in the oven at $105^{\circ} \mathrm{C}$ for $24 \mathrm{~h}$. The dried EFB fibres were grounded and sieved using a mechanical sieve to obtain homogenous sample size within the range 250-500 $\mu \mathrm{m}$. The prepared EFB fibres were stored in dessicator prior to be used. The POME was supplied by Palm Oil Mill factory in Labu, Negeri Sembilan.

\section{EFB CELLULOSE EXTRACTION METHOD}

EFB fibres undergo Soxhlet extraction with toluene and ethanol with the ratio of $2: 1$ for 6 to $8 \mathrm{~h}$. Then, EFB fibres were refluxed in $10 \%$ wt. sodium hydroxide $(\mathrm{NaOH})$ solution for $2 \mathrm{~h}$ at $70-80{ }^{\circ} \mathrm{C}$ according to technical in pulp and paper industry (TAPPI-T203). After that, EFB was treated with $1.7 \%$ sodium chlorite $\left(\mathrm{NaClO}_{2}\right)$ and acetate buffer solution for $3 \mathrm{~h}$ at $80-90{ }^{\circ} \mathrm{C}$. The EFB cellulose was obtained according to the NREL standard method and then was dried in desiccator until a constant weight was achieved.

\section{EFB CELLULOSE MODIFICATION}

A mixture of $1.0 \mathrm{~g}$ of oven-dried EFB cellulose with an acetic anhydride/pyridine catalyst blend was heated at 
$100{ }^{\circ} \mathrm{C}$ under reflux in a $50 \mathrm{~mL}$ round-bottom flask at atmospheric pressure for $3 \mathrm{~h}$. The ratio of EFB cellulose mass to AA volume was varied to $1: 20,1: 30,1: 40$ and $1: 50(\mathrm{~g} / \mathrm{mL})$. The amount of pyridine catalyst used was $5 \%$ of the EFB cellulose weight. After the reaction, the product obtained was washed with acetone and methanol with the ratio of 2:1 for $6 \mathrm{~h}$ using the Soxhlet extraction method. This step is important to remove any acetic acid by-product on the modified EFB cellulose. Then the modified EFB cellulose was filtered and the final weight of modified EFB cellulose was recorded. The WPG after the modification was calculated using equation (1).

$$
\text { WPG }(\%)=\left[\frac{\text { weight gain after modification }(\mathrm{g})}{\text { weight of the sample }(\mathrm{g})}\right] \times 100
$$

\section{EFB CELLULOSE CHARACTERIZATION}

The raw EFB fibre, modifed and unmodified EFB celluloses were characterized using several methods and the results obtained were analysed and compared. The FT-IR spectra of each sample was obtained using a spectrophotometer model Perkin Elmer Spectrum 400 FT-IR in the range of 4000 to $400 \mathrm{~cm}^{-1}$. The area and percentage of the crystallinity region of modified EFB cellulose sample was analyzed by X-ray diffraction D8 advance, Bruker AXS Germany with power $40 \mathrm{Kv} 40 \mathrm{Ma}$ by $1 \mathrm{D}$ fast detector.

\section{DEGREE OF HYDROPHOBICITY (DH)}

About $0.1 \mathrm{~g}$ modified EFB cellulose was placed in the beaker containg $5 \mathrm{~mL}$ coloured distilled water and it was stirred for $10 \mathrm{~min}$. Then, equivalent volume of $\mathrm{n}$-hexane solvent that act as non-polar material was added and was continuously stirred for another $3 \mathrm{~min}$ (Jahi et al. 2015). After the two separation phases were formed, the modified EFB cellulose in n-hexane layer was collected by filtration technique (Cai et al. 2013). The DH was calculated based on (2).

$$
\mathrm{DH}(\%)=\left[\frac{\text { weight sample in } \mathrm{n} \text {-hexane }(\mathrm{g})}{\text { weight of the sample }(\mathrm{g})}\right] \times 100
$$

\section{MORPHOLOGY ANALYSIS}

The microstructure of raw EFB, EFB cellulose, modified EFB cellulose in optimum ratio and modified EFB cellulose after oil absorbed were investigated with a SEM Ziess Model at an accelerated voltage of $25 \mathrm{kV}$, at a beam angle of $90^{\circ}$. Micrographs of sample at magnifications ranging from 100 to $5000 \times$ and various pyrolysis temperatures, were used to explain the effects of AA as a modification agent on the microstructure of adsorbants.

\section{BOD AND COD TEST}

Biochemical oxygen demand (BOD) test is very important especially for determination of wastewater quality by measuring the oxygen consumed by microorganisms under specific condition. The preparation of sample for BOD test was conducted based on American Public Health Association (APHA) standard method 5210 (APHA 2005). This test used $60 \mathrm{~mL}$ of POME before and after treatment with modified EFB cellulose adsorbant that was placed in the dark reagent bottle. The determination process was conducted in a 3 day incubation period. In contrast, chemical oxygen demand (COD) test was conducted to quantify the amount of organic matter in the water by using oxidising agent. The POME sample was preferably collected in glass bottles and preparation of sample solution was conducted based on standard method APHA 5220 (APHA 2005).

\section{OIL SORPTION CAPACITY}

Prior to adsorption test, water content in the POME was determined. $13 \mathrm{~mL}$ of POME was dried in the oven at $60{ }^{\circ} \mathrm{C}$ for $4 \mathrm{~h}$ to remove water content that was found in POME. Oil was extracted from POME using Soxhlet extraction and $n$-hexane as solvent. The solvent was evaporated by rotary vapour. The end product, which was oil residue, was collected and weighed (m).

The modified EFB cellulose was subjected for POME adsorption test and $\mathrm{pH}$ of the POME was adjusted to $\mathrm{pH} 7$ with $0.1 \mathrm{M}$ sodium hydroxide $(\mathrm{NaOH}) .1 .0 \mathrm{~g}$ of modified EFB cellulose was added in the beaker containing $13 \mathrm{~mL}$ of POME. The sample was stirred at 70 rpm for $30 \mathrm{~min}$ at room temperature. After equilibrium was achieved, the sample was filtered and the residue was collected on a petri dish and was dried in oven until a constant weight was achieved. The oil adsorbed by EFB cellulose then was extracted by $n$-hexane in Soxhlet extractor for several hours until the colour of n-hexane solvent was unchanged. Finally, n-hexane was evaporated by using rotary evaporator and the weight of the extracted oil $\left(\mathrm{m}_{\mathrm{o}}\right)$ was measured. Then, the percent of oil absorbed by the modified EFB cellulose was calculated based on (3).

Oil adsorbed capacity $(\%)=\left(\frac{m-m_{0}}{m_{\circ}}\right) \times 100 \%$

where $m_{o}$ is the initial mass of sorbent material, and $m$ is the final mass of sorbent material.

\section{RESULTS AND DISCUSSION}

Acetylation is a single-addition reaction which means that one acetyl group reacts to one hydroxyl group with no polymerization (Fan et al. 2013). Thus, all weight gain in acetyl can be directly converted into units of hydroxyl group blocked. The replacement of some hydroxyl group on the cell wall polymers with bonded acetyl groups reduces the hygroscopy of wood. Moisture is presumed to be sorbed either as primary or secondary water. 


\section{WEIGHT PERCENT GAIN (WPG)}

The ratio of EFB cellulose to AA concentration as a modified reagent played a significant role on the WPG value and many of the acetylated samples properties were dependent on the method of acetylation. The amount of moisture present in the cellulose fibre is also important. The moisture content $(2-5 \%)$ seems to be necessary for the best reaction. These loses via hydrolysis accounted for a $5.7 \%$ loss of anhydride for each $1 \%$ of water in the cellulose fibres and the decreasing rate of acetylation as moisture content increase.

Since cellulose constitutes the majority of EFB cellulose and lignin contains little hydroxyl, AA has to react primarily with the hydroxyl groups of cellulose. Due to the chemical heterogeinity of EFB cellulose, the degree of substitution for the acetylation process was hard to measure. Instead, the extent of acetylation was evaluated by determining the WPG. The higher the weight gained of modified EFB cellulose, the higher the degree of substitution. Table 1 shows the WPG for modified EFB cellulose in ratio $1: 20,1: 30$, and $1: 40(\mathrm{~g} / \mathrm{mL})$ increased as the modified EFB cellulose mass to AA volume increased except for 1:50.

The decrease in WPG for modified EFB cellulose (1:50) may have occurred due to the degradation of carbohydrates which are cellulose and hemicellulose under strong acidic conditions (Hu et al. 2011; Huang et al. 2014). The degradation products were dissolved in the reaction solution and could not be collected in the solidliquid separation process through filtration and caused WPG to decrease. Sample 1:40 showed the highest WPG which is $13.04 \%$ with a $5 \% \mathrm{w} / \mathrm{v}$ catalyst concentration at $3 \mathrm{~h}$ reaction time.

\section{STRUCTURE AND SURFACE FUNCTIONAL GROUPS}

FTIR spectra of raw EFB, EFB cellulose, and modified EFB cellulose in ratio $(\mathrm{g} / \mathrm{mL}) 1: 20,1: 30,1: 40$ and 1:50 showed in Figure 1. The intensity peak at $3340-3329 \mathrm{~cm}^{-1}$ is attributed to $-\mathrm{OH}$ stretching in cellulose structure that was found in all samples. While the intensity of $-\mathrm{OH}$ band at $3329 \mathrm{~cm}^{-1}$ decreased due acetylation from modified EFB cellulose in ratio 1:50>1:20>1:30>1:40. It indicated that the number $-\mathrm{OH}$ groups decreased due to the substitution of the acetyl group during the increasing AA concentration in acetylation reaction. The wavenumber range of 2916 - $2900 \mathrm{~cm}^{-1}$ on raw EFB and EFB cellulose samples refer to the intensity of functional $\mathrm{C}-\mathrm{H}$ stretching vibration that appear on all samples that was found in the cellulose structure. The new peaks at $1728 \mathrm{~cm}^{-1}$ was attributed to the functional group $\mathrm{C}=\mathrm{O}$ stretching the acetyl group on modified EFB cellulose. There is clear evidence that the peak around wavelength $1370 \mathrm{~cm}^{-1}$ appeared due to modified EFB cellulose, the peak refers to $\mathrm{C}-\mathrm{H}$ deformations in $\mathrm{CH}_{3}$ from acetyl groups and the intensity increased with increasing ratio. The peak at wavelength $1243 \mathrm{~cm}^{-1}$ is attributed to the stretching of $\mathrm{C}-\mathrm{O}$ and $\mathrm{C}=\mathrm{O}$ deformation of the ester bond. The intensity of ester bands increased with higher concentration of AA implying that acetylation process was successful except for 1:50 ratio. The peak at $1242 \mathrm{~cm}^{-1}$ of raw EFB spectrum was attributed to a waxy acetyl group of hemicellulose ester or carbonyl ester of p-coumeric lignin unit. The strong appearance of this peak comes from apart of the acetic anhydride $\left(\mathrm{CH}_{3} \mathrm{CO}\right)_{2} \mathrm{O}$ structure. Raw EFB samples had undergone alkaline and acidic hydrolysis treatment to expose their cellulose fibre due the removing of lignin and hemicellulose part. The peak at $897 \mathrm{~cm}^{-1}$ is assigned to the $\beta$-glycosidic linkage that connected the bond to the alcohol functional group in cellulose structure.

\section{DEGREE OF HIDROPHOBICITY (DH)}

The percentage of DH for modified EFB cellulose is defined as the tendency of the materials to be removed from polar phase into a non-polar phase (Jahi et al. 2015; Jonoobi et al. 2010). Based on Table 2, the DH value for modified EFB cellulose in ratio had increased due to modification. The modified EFB cellulose (1:40) showed a highest DH compared to the other samples. This means that modification in ratio 1:40 was successful due to the substitution of $\mathrm{C}=\mathrm{O}$ and $\mathrm{C}-\mathrm{O}$ in the EFB cellulose. $\mathrm{DH}$ is related to the percentage of degree of substitution of $-\mathrm{OH}$ group by $\left(\mathrm{CH}_{3} \mathrm{CO}\right)_{2} \mathrm{O}$ chain on the surface $\mathrm{EFB}$ cellulose. In contrast, the EFB cellulose showed poor efficiency for oil waste absorption. This was expected as EFB cellulose usually exhibited low sorption capacity due to presence of many hydroxyl group on its surface. The presence of hydroxyl groups on the surface of EFB cellulose is hypothesized to repel oil molecules in the absorption medium, thus reducing the absorption uptake.

The effectiveness of AA in increasing the affinity of modified EFB cellulose to absorb oil was proven with the increase in the absorption medium thus increased the adsorption uptake of modified EFB cellulose. The introduction of acetic anhydride $\left(\mathrm{CH}_{3} \mathrm{CO}\right)_{2} \mathrm{O}$ chain to the EFB cellulose that was rich with hydroxyl groups promotes the esterification process. The substitution of hydroxyl group with the carbonyl chain from acetic anhydride $\left(\mathrm{CH}_{3} \mathrm{CO}\right)_{2} \mathrm{O}$ has led to the creation of a non-polar layer on the modified EFB cellulose surface and also can make the hydrophilic surface of cellulose more hydrophobic (Jonoobi et al. 2010).

The increase in the hydrophobicity degree and the increasing of amorphous region of modified EFB cellulose is believed to enhance and provide more superior sites for higher oil adsorption uptake (Said et al. 2009). This result is in agreement with FTIR and XRD analysis 
and since modified EFB cellulose in ratio 1:40 is more hydrophobic, it is expected that it will absorb more oil and non-polar substituents in POME compared to $1: 20,1: 30$ and 1:50.

\section{X-RAY DIFFRACTION (XRD)}

The morphological changes and effects of chemical treatment on crystallinity of EFB samples can be evaluated via XRD curve. Figure 2 represents the XRD curves of raw EFB (a), EFB cellulose (b), modified EFB cellulose in ratio 1:20 (c), 1:30 (d) 1:40 (e) and 1:50 (f). The XRD of heterogenous acetylation reaction indicates crystallinity changes during acetylation when using heterogenous condition. The peak localized at $12^{\circ}-15^{\circ}, 22^{\circ}$ and $35^{\circ}$ were assigned to reflections of crystalline planes of cellulose in EFB cellulose fibers. The diffraction peak at 2-Theta of $18^{\circ}$ was due to the amourphous regions in the cellulose of raw EFB. As it may be noted from the XRD curves for sample (a), (c), (d), (e) and (f), the relative height of the diffraction peak of the amourphous regions $\left(18^{\circ}\right)$ increase, while the relative height of the diffraction of the four crystal planes decrease and a main broad peak located at around $9^{\circ}$ is observed in modified EFB cellulose. The peak located at approximately $9^{\circ}$ was cited as the principle characteristics of semicrystalline acetylated derivative cellulose. The position of this peak indicates the generation of a disorder when the EFB cellulose are modified.

The disorder is caused by the projection of the subtituting groups (acetyl group) along the axes and is associated with an increase in the interfibrillar distances, as well as the breakdown of microfibrillar structure. The degree of crystallinity for sample 1:40 (57\%) is much lower than of raw $(64 \%)$. The value of the crystallinity index on Table 3 was obtained by the calculation of the two types of substances using crystallinity formula, which means that the hydrogen bonding was weakened as hydrogen groups were substituted with acetyl groups that have the larger volume. In addition, a small peak arisen at 2-Theta from $10^{\circ}$ to $20^{\circ}$ show the presence of small amount of triacetate inmodified EFB cellulose product.

\section{SURFACE MORPHOLOGY}

The SEM images for surface morphologies of raw EFB (a), EFB cellulose (b), modified EFB cellulose (1:40) (c) and modified EFB cellulose after oil adsorbed (d) were shown in Figure 3, it can be seen that the surface morphologies have changed after the treatments. Raw EFB exhibits a smooth surface without any ripples due a coat of plant wax, while the surface of treated samples is rough and has different degrees of wrinkles and grooves. This suggests that the surface wax of treated EFB cellulose has been removed and the hydrophilic surface is exposed. For alkaline treated EFB fibre, the trivial fibrils broken hole and shallow pit can give serious damage to the structure of the EFB fibre resulting in the collapse of hollow tubes. Then, for sample modified EFB cellulose after oil adsorption test showed smooth and shiny surface affected by adhesion of oil waste. In general, the coarse surface will increase the surface area of EFB fibre.

The illustration on chemical reaction between EFB cellulose with AA reagent in Figure 4 was used to explain how EFB cellulose reacts with AA to create a hydrophobic character. The EFB cellulose fibre has a very strong structure with a high crystallity region making it difficult for the reactant to penetrate the EFB cellulose. Regarding to that, heating was supplied as energy to break the hydrogen bond to provide accessible sites on EFB cellulose and pyridine was used as a catalyst to enhance the rate of reaction on EFB cellulose fiber to create the acetylated EFB cellulose.

In contrast to acetylation reaction of EFB conducted by Asadpour et al. (2016) that using N-bromosuccinimide (NBS) as catalyst, pyridine was used in this study. Pyridine structures have ammine groups as the nucleophilic catalyst. Its initial addition product (a carbinolamine) can become dehydrated because of the free pair of electrons on the $\mathrm{N}$ that more likely to be shared with the carbon, forming a double bond, than the electron from the original carbonyl $\mathrm{O}$, which is more electronegative than the $\mathrm{N}$. Then, the transfer of the proton to the oxygen gives it a positive charge. Secondly, the positive charge on the carbon atom is attracted by one of the lone pairs of the oxygen on the glucose structure. Next, the acetylated EFB cellulose was created by the removing hydrogen from the oxygen through reaction with the initial addition product a carbinolamine that was produced from early reaction. The substitution of $\mathrm{OH}$ groups with the acetyl group from AA chain has lead to the creation of a non-polar layer on the modified EFB cellulose surface.

\section{PERFORMANCE OF MODIFIED EFB CELLULOSE AS OIL SORBENT}

Figure 5 shows that the oil absorption test of the modified EFB cellulose for ratio 1:20, 1:30, 1:40 and 1:50 in the POME sample. The POME samples have two main phase which are oil and water. Based on the result, the oil absorbed increases from samples of ratio 1:20, 1:30 and 1:40 but weak performance showed up in sample 1:50 with the oil absorbed percentage are 96.5, 97.4, 98.5 and $16.0 \%$, respectively. This implies that the surface modified EFB cellulose substituted with acetyl group are very effective in improving their oil sorption capability.

The oil affinity of modified EFB cellulose was markedly improved by roughing the surface and lowering the surface energy after modification process. The roughing of the modified EFB cellulose that cause the swelling was affected by pyridine for easy penetration of modification reagent on the EFB cellulose fibre chain. 
Additionally, the findings of this study implies that the surface roughness of modified EFB cellulose is an important factor that influences its oil sorption capability. Due to better chemical compatibility between oil and modified fibre surface with non-polar reagent, it is easier to overcome a minimum energy barrier to penetrate into the fibre interstice and hollow lumen. The effectiveness of AA in increasing the affinity of modified EFB cellulose to adsorb oil was proven with the increase in the absorption uptake of modified EFB cellulose in ratio 1:20, 1:30 and $1: 40$ are $96.5,97.4$ and $98.5 \%$, respectively.

\section{BOD AND COD VALUE OF TREATED POME}

Based on Table 4, the BOD value for the POME sample showed a significant decrease after the oil absorption test was carried out using modified EFB cellulose as adsorbant. This proves that the modified EFB cellulose has managed to lower the value of BOD in POME up to $78 \%$. The declined BOD value is believed due to the reduction of organic matter that gives blackish colour in the POME sample.

Additionally, based on Table 4 it can be seen that the COD value also shows a significant reduction. COD refers to oxygen content equivalent to a sample of organic material that is easily oxidized when it is subjected to a strong oxidizing agent. POME have typical COD value at $50000 \mathrm{mgL}^{-1}$ (Ibrahim et al. 2010). After the treatment of oil waste absorption using modified EFB cellulose, COD values decreased by $18 \%$. This shows that the presence of certain organic substances is diminishing after the treatment of oil waste absorption by modified EFB cellulose. The production of oil absorbant from modified EFB cellulose has high efficiency in oil absorption and has a good performance in reducing of COD value in POME that give advantage to protect our ecosystem from land and water pollution cause by palm oil mill activities.

TABLE 1. Weight percent gain (WPG)

\begin{tabular}{cc}
\hline Sample & WPG $(\%)$ \\
\hline $1: 20$ & 3.4 \\
$1: 30$ & 11.3 \\
$1: 40$ & 13.0 \\
$1: 50$ & 2.6 \\
\hline
\end{tabular}

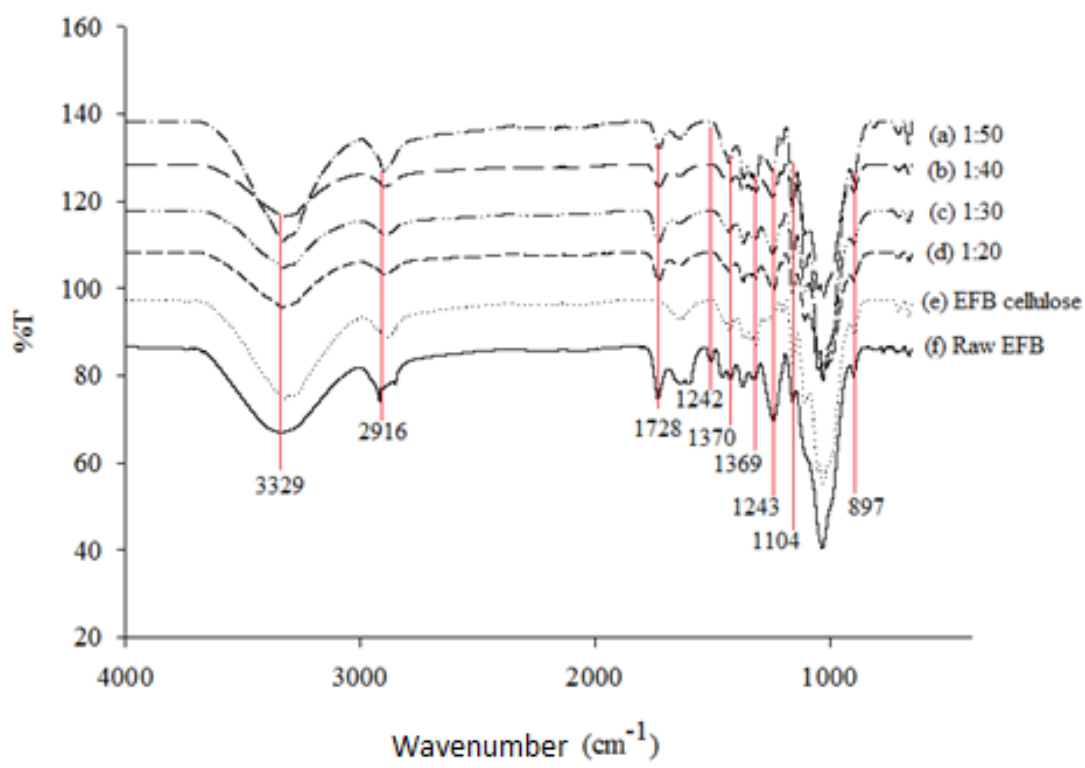

FIGURE 1. Fourier-transform infrared (FTIR) spectra of (a) 1:50, (b)1:40 and (c) 1:30, (d) 1:20, (e) EFB cellulose and (f) Raw EFB 
TABLE 2 . The hydrophobicity degree (DH)

\begin{tabular}{cc}
\hline Sample & DH (\%) \\
\hline EFB cellulose & - \\
$1: 20$ & 82.0 \\
$1: 30$ & 84.0 \\
$1: 40$ & 87.7 \\
$1: 50$ & 29.0 \\
\hline
\end{tabular}

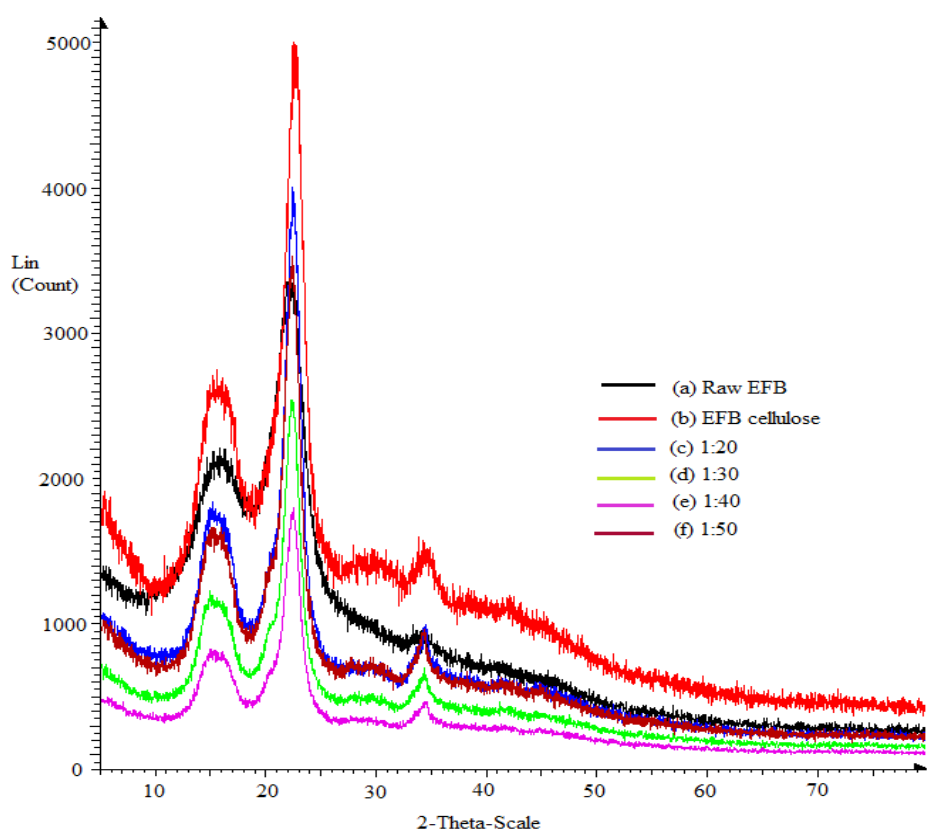

FIGURE 2. X-ray diffraction profile of (a) Raw EFB, (b) EFB cellulose, modified EFB cellulose (c) 1:20, (d) $1: 30$, (e) $1: 40$ and (f) 1:50

TABLE 3. The percentage of crystallinity index

\begin{tabular}{cc}
\hline Sample & $\mathrm{C}_{\mathrm{ir}}(\%)$ \\
\hline EFB celullose & 64 \\
$1: 20$ & 61 \\
$1: 30$ & 59 \\
$1: 40$ & 57 \\
$1: 50$ & 63 \\
\hline
\end{tabular}




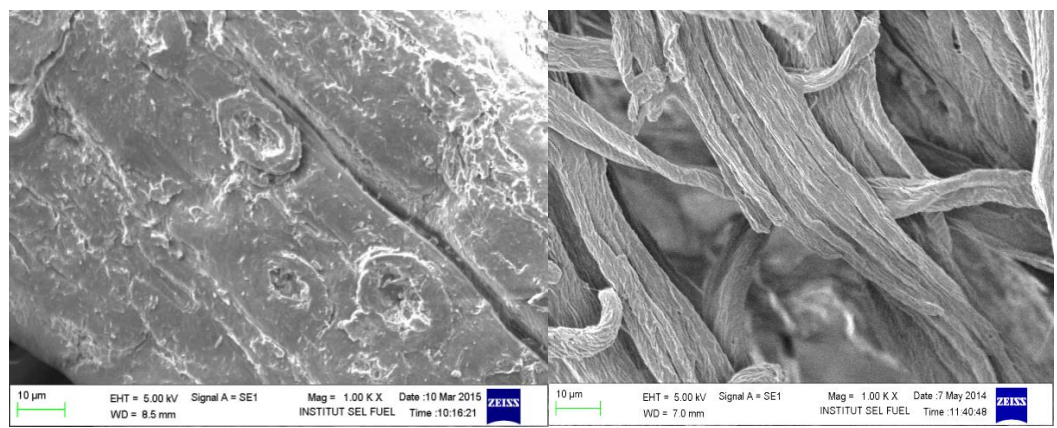

(a)

(b)

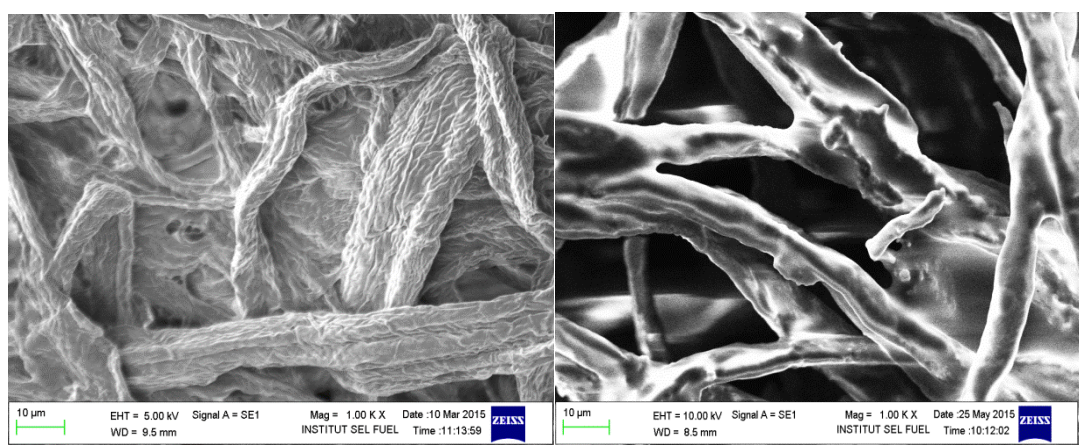

(c)

(d)

FIGURE 3. SEM images of (a) Raw EFB, (b) EFB cellulose, (c) Modified EFB cellulose (1:40), and (d) Modified EFB cellulose after oil absorbed

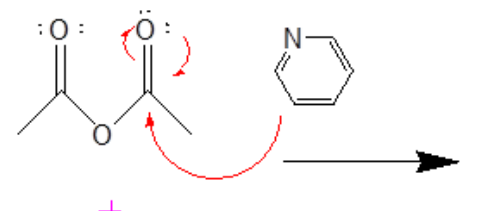

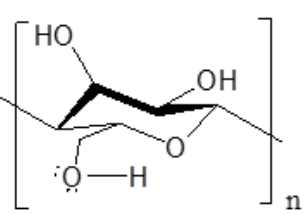<smiles>CC(=O)OCC(C)(C)ON1CCCC1</smiles><smiles>CC1COC(C)C(O)C(C)C1O</smiles>

Intermediate cellulose

EFB cellulose

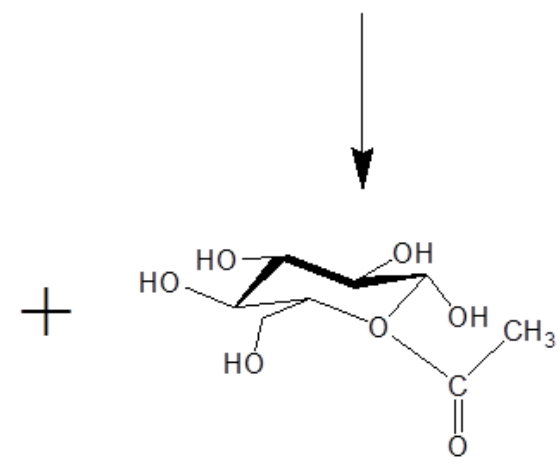

Acetylated EFB cellulose

FIGURE 4. Chemical reaction of EFB cellulose fibre with acetic anhydride (AA) 


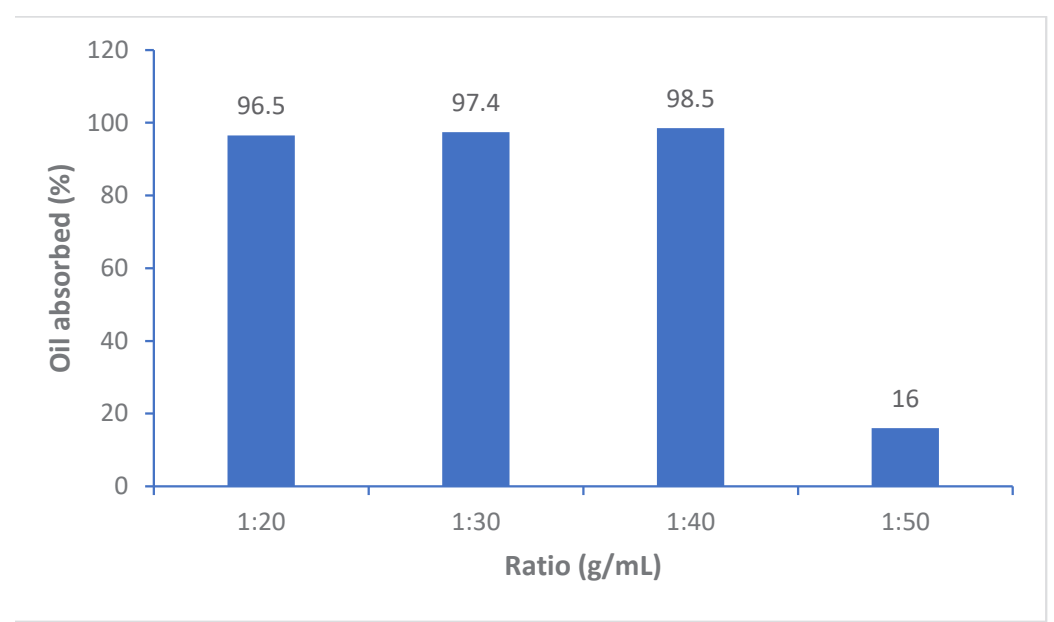

FIGURE 5. Percentage oil absorbed capacity (\%)

TABLE 4. BOD and COD test result

\begin{tabular}{|c|c|c|c|c|c|c|c|}
\hline \multirow[t]{3}{*}{ Parameter } & \multirow[t]{3}{*}{ Unit } & \multicolumn{5}{|c|}{ Test results } & \multirow[t]{3}{*}{ Method } \\
\hline & & \multirow[t]{2}{*}{ Raw EFB } & \multicolumn{4}{|c|}{ Modified EFB cellulose } & \\
\hline & & & $1: 20$ & $1: 30$ & $1: 40$ & $1: 50$ & \\
\hline BOD & $\mathrm{mgL}^{-1}$ & 25000 & 1500 & 9500 & 5510 & 1650 & 5210 \\
\hline COD & $\mathrm{mgL}^{-1}$ & 50000 & 4800 & 4301 & 4100 & 4900 & 5220 \\
\hline
\end{tabular}

\section{CONCLUSION}

The modified EFB cellulose especially 1:40 shows the potential to be an effective oil sorbent in POME. The FTIR analysis, XRD profile and SEM micrograph have elucidated the significant uptake oil from POME onto EFB cellulose. The successful impregnation of AA in EFB cellulose was supported by all the analysis studied. Modified EFB cellulose in ratio 1:40 showed the highest of oil adsorbed capacity with $95.5 \%$ within $30 \mathrm{~min}$, thus, make it an extremely promising natural source oil sorption in POME. The advantages of using EFB cellulose as an adsorbent in this study is emphasized in that it is economical and stands as a solution to the environmental problems due to the abundances of EFB in South East region, especially Malaysia and Indonesia.

\section{ACKNOWLEDGEMENTS}

The authors would like to thank Universiti Kebangsaan Malaysia and the Ministry of Higher Education, Malaysia for supporting this work through the GGP-2017087, GUP-2018-058, and FRGS/1/2019/STG01/UKM/02/15 as well as Centre for Research Instrumentation and Management (CRIM-UKM).

\section{REFERENCES}

Abdullah, M.A., Rahmah, A.U. \& Man, Z. 2010. Physicochemical and sorption characteristics of Malaysian Ceiba pentandra (L.) Gaertn. as a natural oil sorbent. Journal of Hazardous Materials 177(1): 683-691.

Anuar, N.I.S., Zakaria, S., Kaco, H., Hua, C.C., Chunhong, W. \& Abdullah, S.H. 2018. Physico-mechanical, chemical composition, thermal degradation and crystallinity of oil 
palm empty fruit bunch, kenaf and propylene fibres: A comparative study. Sains Malaysiana 47(4): 839-851.

APHA. 2005. Standard Methods for the Examination of Water and Wastewater. 21st ed. Washington, DC: American Public Health Association.

Asadpour, R., Sapari, N.B., Isa, M.H. \& Kakooei, S. 2016. Acetylation of oil palm empty fruit bunch fiber as an adsorbent for removal of crude oil. Environmental Science and Pollution Research 23: 11740-11750.

Cai, J., Fei, P., Xiong, Z., Shi, Y., Yan, K. \& Xiong, H. 2013. Surface acetylation of bamboo cellulose: Preparation and rheological properties. Carbohydrate Polymers 92(1): 11-18.

Chen, J., Xu, J., Wang, K., Cao, V. \& Sun, R. 2016. Cellulose acetate fibers prepared from different raw materials with rapid synthesis method. Carbohydrate Polymers 137: 685692.

Deschamps, G., Caruel, H., Borredon, M., Albasi, C., Riba, J., Bonnin, C. \& Vignoles, C. 2003. Oil removal from water by sorption on hydrophobic cotton fibers. Study of sorption properties in dynamic mode. Environmental Science and Technology 37(21): 504-5039.

Fan, G., Wang, M., Liao, C., Fang, T., Li, J. \& Zhou, R. 2013. Isolation of cellulose from rice straw and its conversion into cellulose acetate catalyzed by phosphotungstic acid. Carbohydrate Polymers 94(1): 71-76.

Hamdan, W.N.A.N.M., Haan, T.Y. \& Mohammad, A.W. 2018. Sustainable approach in palm oil industry-Green synthesis of palm oil mill effluent based graphene sand composite (P-GSC) for aerobic palm oil mill effluent treatment. Jurnal Kejuruteraan SI 1(7): 11-20.

Hamzah, F., Idris, A. \& Shuan, T.K. 2011. Preliminary study on enzymatic hydrolysis of treated oil palm (Elaeis) empty fruit bunches fibre (EFB) by using combination of cellulose and $\beta$ 1-4 glucosidase. Biomass Bioenergy 35: 1055-1059.

Hamzah, M.A.F., Jahim, M.J., Abdul, P.M. \& Asis, A.J. 2019. Investigation of temperature effect on start-up operation from digestion of acidified palm oil mill effluent. Energies 12(13): 2473-2489.

Hassan, M.A.A. \& Puteh, M.H. 2007. Pre-treatment of palm oil mill effluent (POME): A comparison study using chitosan and alum. Malaysian Journal of Civil Engineering 19(2): 128-141.

Hassan, N., Idris, A. \& Akhtar, J. 2019. Overview on bio-refinery concept in Malaysia: Potential high value added products from palm oil biomass. Jurnal Kejuruteraan SI 2(1): 113-124.

Hazman, N.A.S., Yasin, N.H.M., Takriff, M.S., Hassan, H.A., Kamaruddin, K.F. \& Hakimi, N.I.N.M. 2018. Integrated palm oil mill effluent treatment and $\mathrm{CO}_{2}$ sequestration by microalgae. Sains Malaysiana 47(7): 1455-1464.

Hu, C., Reddy, N., Luo, Y., Yan, K. \& Yang, Y. 2011. Thermoplastics from acetylated zein-and-oil-free corn distillers dried grains with solubles. Biomass and Bioenergy 35(2): 884-892.

Huang, K., Zhang, M., Zhang, G., Jiang, X. \& Huang, D. 2014. Acetylation modification of rice straw fiber and its thermal properties. Cellulose Chemistry and Technology 48: 199207.

Ibrahim, S., Wang, S. \& Ang, H.M. 2010. Removal of emulsified oil from oily wastewater using agricultural waste barley straw. Biochemical Engineering Journal 49(1): 78-83.
Jahi, N., Engsiew, L., Othaman, R. \& Ramli, S. 2015. Modification of oil palm plantation wastes as oil adsorbent for palm oil mill effluent (POME). Malaysian Journal of Analytical Sciences 19(1): 31-40.

Jasni, J., Arisht, S.N., Yasin, N.H.M., Abdul, P.M., Lin, S.K., Liu, C.M., Wu, S.Y., Jahim, J.M. \& Takriff, M.S. 2020. Comparative toxicity effect of organic and inorganic substances in palm oil mill effluent (POME) using native microalgae species. Journal of Water Process Engineering 34(2020): 101165.

Jonoobi, M., Harun, J., Mathew, A.P., Hussein, M.Z.B. \& Oksman, K. 2010. Preparation of cellulose nanofibers with hydrophobic surface characteristics. Cellulose 17(2): 299-307.

Joseph, C.G., Wan Mohd Ashri Wan Daud, Shane, Q.K. \& Kogularama Sanmugam. 2015. Parametric and adsorption kinetic studies of reactive black 5 removal from textile simulated wastewater using oil palm (Elaeis guineensis) empty fruit bunch. Journal of Applied Sciences 15(8): 1103-1111.

Kasim, N.N., Ismail, K., Ishak, M.A.M., Ahmad, R., Mohamed, A.R. \& Nawawi, W.I. 2017. PALM DeTo: Resourceful, sustainable and favorable solid biofuel. Symposium on Innovation and Creativity (iMIT-SIC) 2: 191-197.

Lv, E., Xia, W., Tang, M. \& Pu, Y. 2017. Preparation of an efficient oil-spill adsorbent based on wheat straw. BioResources 12(1): 296-315.

Mahadeva, S.K., Yun, S. \& Kim, J. 2011. Flexible humidity and temperature sensor based on cellulose-polypyrrole nanocomposite. Sensors and Actuators A: Physical 165(2): 194-199.

MPOB. 2015. Malaysian Oil Palm Statistic 2015. $35^{\text {th }}$ edition. MPOB, Bangi. p. 28.

Onwuka, J.C., Agbaji, E.B., Ajibola, V.O. \& Okibe, F.G. 2018. Treatment of crude oil-contaminated water with chemically modified natural fiber. Applied Water Science 8: 86 .

Onwuka, J.C., Agbaji, E.B., Ajibola, V.O. \& Okibe, F.G. 2016. Kinetic studies of surface modification of lignocellulosic Delonix regia pods as sorbent for crude oil spill in water. Journal of Applied Research and Technology 14: 415-424.

Pirani, S. \& Hashaikeh, R. 2013. Nanocrystalline cellulose extraction process and utilization of the byproduct for biofuels production. Carbohydrate Polymers 93(1): 357 363.

Roslan, R., Zakaria, S., Chia, C.H., Boehm, R. \& Laborie, M.P. 2014. Physico-mechanical properties of resol phenolic adhesives derived from liquefaction of oil palm empty fruit bunch fibres. Industrial Crops and Products 62: 119-124.

Said, A.E.A., Ludwick, A.G. \& Aglan, H.A. 2009. Usefulness of raw bagasse for oil absorption: A comparison of raw and acylated bagasse and their components. Bioresource Technology 100(7): 2219-2222.

Sajab, M.S., Jauhari, W.N.W.A.R., Chia, C.H., Zakaria, S., Kaco, H. \& Noor, A.A.M. 2018. Oleophilicity and oil-water separation by reduced graphene oxide grafted oil palm empty fruit bunch fibres. Sains Malaysiana 47(8): 18911896.

Takriff, M.S., Jaafar, N.L. \& Abdullah, S.R.S. 2014. A review of biofilm treatment systems in treating downstream palm 
oil mill effluent (POME). Journal of Applied Sciences 14: 1334-138.

Yamada, H., Tanaka, R., Sulaiman, O., Hashim, R., Hamid, Z.A.A. \& Yahya, M.K.A. 2010. Old oil palm trunk: A promising source of sugars for bioethanol production. Biomass Bioenergy 34: 1608-1613.

Zakaria, S., Roslan, R., Amran, U.A., Chia, C.H. \& Bakaruddin, S.B. 2014. Characterization of residue from EFB and kenaf core fibres in the liquefaction process. Sains Malaysiana 43(3): 429-435.

Noraisah Jahi, Rizafizah Othaman, Azwan Mat Lazim \& Suria Ramli*

Department of Chemical Sciences

Faculty of Science and Technology

Universiti Kebangsaan Malaysia

43600 UKM Bangi, Selangor Darul Ehsan

Malaysia
Rizafizah Othaman, Azwan Mat Lazim \& Suria Ramli* Polymer Research Center (PORCE)

Faculty of Science and Technology

Universiti Kebangsaan Malaysia

43600 UKM Bangi, Selangor Darul Ehsan

Malaysia

Suria Ramli*

Center for Water Research and Analysis (ALIR)

Faculty of Science and Technology

Universiti Kebangsaan Malaysia

43600 UKM Bangi, Selangor Darul Ehsan

Malaysia

*Corresponding author; email: su_ramli@ukm.edu.my

Received: 15 October 2019

Accepted: 8 May 2020 